\title{
Popüler Roman / Estetik Roman Kavramları ve Așk Romanı
}

\section{Popular Roman / Aesthetic Roman Concepts and Novel of Așk}

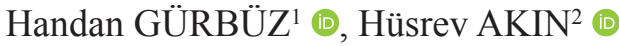

'Handan Gürbüz (Doktora Öğrencisi),

Erzincan Binali Yıldırım Üniversitesi, Sosyal Bilimler Enstitüsü, Erzincan, Türkiye.

E-posta: handan_gurbuz24@hotmail.com ORCID: 0000-0003-3343-4828

${ }^{2}$ Sorumlu yazar/Corresponding author: Hüsrev Akın (Dr. Öğr. Üyesi),

Erzincan Binali Yıldırım Üniversitesi Fen Edebiyat

Fakültesi, Erzincan, Türkiye.

E-posta: husrevakin@gmail.com

ORCID: 0000-0002-9844-1781

Başvuru/Submitted: 11.02.2020

Revizyon Talebi/Revision Requested:

18.02.2020

Son Revizyon/Last Revision Received:

06.03.2020

Kabul/Accepted: 15.04 .2020

Online Yayın/Published Online: 15.05 .2020

Atıf/Citation: Gurbuz Handan ve Akin Husrev. "Popüler Roman / Estetik Roman Kavramları ve Aşk Romanı." Türkiyat Mecmuası-Journal of Turkology 30, 1 (2020): 1-23.

https://doi.org/10.26650/iuturkiyat.687895

\section{öz}

Elif Şafak, son dönem romancılarımız arasında adından sıkça bahsedilen yazarlardan biridir. Aşk'a kadar sırasıyla Pinhan, Şehrin Aynaları, Mahrem, Bit Palas, Araf, Baba ve Piç, Siyah Süt adlı eserlerini yayımlar. Bunların her biri tanınırlığının artmasına katkı sağlar. Fakat onun hem uluslararası başarı ödüllerine layık görülmesinde hem de Türk yayın dünyasında kısa sürede en çok satılan kitabın yazarı olmasında etkili olan Aşk'tır. Aşk, ilk önce The Forty Rules of Love adıyla yurtdışında daha sonra da $A$ şk adıyla Türkiye'de yayımlanır. Elif Şafak eserde bir tarafta Ella-Zahara bir tarafta da Mevlana-Şems aşkını işler.

Tasavvufi mahiyette olan bu eserin popüler mi yoksa estetik mi olduğu konusunda bugüne kadar bir çalışma yapılmamıştır. Bu sebeple makalenin giriş kısmında popüler ve estetik roman konusuna değinilmiştir. Daha sonra Elif Şafak'ın Aşk romanı popüler ve estetik roman unsurlarından hareketle hem içerik hem de biçim açısından karşılaştırma ve doküman analizi metotlarıyla değerlendirilmiştir. Böylece Elif Şafak'ın Aşk romanının edebiyat dünyasındaki asıl yeri tespit edilmeye çalışmıştır.

Anahtar kelimeler: Elif Şafak, Cumhuriyet Dönemi, Aşk romanı, popüler roman, estetik roman

\section{ABSTRACT}

Elif Şafak is a novel writer whose name is frequently mentioned among contemporary novelists. Before Aşk, she published her works Pinhan, Şehrin Aynaları, Mahrem, Bit Palas, Araf, Baba ve Piç, Siyah Süt respectively. Each of these contributed to her recognition. However, it is $A$ şk that is profound in both being deemed worthy of international success awards and making her the author of the best-selling book in the Turkish publishing world in a short time. Aşk, first published abroad in the name The Forty Rules of Love, is published in Turkey in the name Aşk. Elif Şafak handles the love of Ella-Zahara on the one hand and Mevlana-Şems on the other.

No study has been carried out up to today as to whether this sufistic work is popular or aesthetic. In the introduction part of the study, the topic of the popular and aesthetic novel is mentioned. Then, Elif Şafak's $A$ şk novel has been evaluated in terms of both content and form based on popular and aesthetic novel elements. This evaluation has been done by comparison and document analysis methods. Thus, it has been attempted to determine the original place of Elif Şafak's Aşk novel in the literary world.

Keywords: Elif Şafak, Republican Period, Aşk, popular novel, aesthetic novel 


\section{EXTENDED ABSTRACT}

The word "popular" is used for things that are new and which differ from others. Their popularity also declines as popular things start to age. Culture, art and novels are also influenced by popularity. Although popular culture is fed from traditional culture, it is a contemporary culture that differs from it in terms of structure. Because this culture is not traditional, it is popular; it depends on time and condition. Pop-art is the name given to works created which include references to known people and objects of the period. The worst part of pop-art is that it is consumed very quickly and is obliged to be forgotten. This situation is related to whether it conforms to the expectations and wishes of the consumer.

In popular novels, writers create works that will appeal to the reader's emotional world. For this reason, they handle the issues of love, jealousy and betrayal, which are of interest to most readers. No gap is left in the fiction of these works. The reader is passive in popular novels from beginning to end. However, popular novels can make readers believe that others experience problems similar to those experienced by themselves or their relatives. This allows the reader to share the same emotions with the novel character. The reactions of the novel characters to the events can also be imitated by the reader in real life.

Aesthetics comes from the Greek word aishesis. Aesthetics is a branch of philosophy that deals with the effect of beauty on human. There are 4 basic elements that make up the aesthetic entity. These are aesthetic subjects, aesthetic objects, aesthetic values and aesthetic judgments. If any of these four items are missing, the work cannot be said to be aesthetic.

Art works differ from others in terms of their aesthetic values they own. The narrative in aesthetic novels is not as clear as in popular novels. Only the reader, who has a certain level of knowledge and culture, can grasp the narrative in line with the clues the author offers him. In this respect, the reader tries to complete the gaps in the fiction throughout the novel.

Aesthetic novels are not event centered. What is important for aesthetic novel writers is to give the inner world and conflicts of the person. In this regard, coincidences, stereotypes, unnecessary depictions are not included in aesthetic works. Techniques such as the internal monologue and the flow of consciousness are used in order to highlight the conflicts of the novel's characters.

Aesthetic novels can be read many times. Each time it is read, it reveals aspects that were not previously noticed. For this reason, aesthetic works are immortal, each of them is original. Ahmet Hamdi Tanpınar's Huzur and Peyami Safa's Yalnızız novels are unique because of their aesthetic features.

Aesthetic novel writers care about the form of their works as much as their content. By writing novels that are almost flawless, they enable the reader to experience aesthetic pleasure. They do this with the meanings they impose with the combination of words. The aim of the aesthetic novel writer is to impress the reader. Accordingly, they do not engage in actions such as teaching, reminding or imposing something; they do not have commercial concerns; they 
pursue writing good and beautiful works.

Based on the unique structure of popular and aesthetic works as mentioned above, by analyzing the content and formal structure of a work, it can be revealed whether it is aesthetic or popular. When Elif Şafak's Aşk novel is examined in terms of plot, narrator and point of view, people, time, place, fiction and expression level, expression techniques, language and style, it turns out that the work is closer to the popular novel.

Elif Şafak does not leave any blanks in the story of the novel $A s ̧ k$. The reader is passive from the beginning to the end of the novel. In the novel, the story of Şems-Mevlana is presented to the reader with a plural narrator. Şems, Rumi, Çömez, Alaaddin, Baybars, Baba Zaman, Çöl Gülü, Mutaassıp, Talebe Hüsam, Kerra, Sultan Veled, Süleyman, Kimya, Şeyh Yasin and Katil tell the events from their own perspective. The usage of plural perspective seems to add an aesthetic atmosphere to the novel. However, Elif Şafak constantly wants to send a message to the reader. Therefore, she does not leave the narrator characters to their own devices.

Elif Şafak minimizes the depiction of people in her work; she tries to highlight them with the change which they experience. In doing so, the author ignores the psychological and subconscious narratives of the characters. She cannot fully show the conflicts of Zahara and Ella. Therefore, Aşk moves away from being aesthetic.

Two different times are mentioned in Aşk. One of them is the time period of the love of Ella and Zahara, and the other is the time of the $13^{\text {th }}$ century. However, the relationship between Mevlana and Shams is the only reality that shows us that the historical time was told in the $13^{\text {th }}$ century events. In this respect, the time period in the novel cannot affect the reader.

In aesthetic novels, there is integrity between space and fiction. The weaknesses in the fiction of $A s ̧ k$ prevent this integrity. Elif Şafak tries to reconcile sufism only with Konya. The author almost forces Zahara, whose movements are incompatible with sufism, to go to Konya. Just because she is in Konya, the morning azan sounds creepy to Ella. Therefore, the aesthetic structure in the spaces of $A s ̧ k$ cannot manifest itself completely.

The formal structure of $A s ̧ k$ brings her closer to the popular novel. The year 2007 was accepted as the Year of the Mevlana by Unesco. Elif Şafak wrote her book in 1.5 years and published it in 2009. This is a sign that the Mevlana-Şems relationship is deliberately used in the work. Elif Şafak draws attention by publishing Aşk at a time when Mevlana was being talked about more and more at home and abroad. In the interviews she participates in, she promotes her work. Moreover, she changes the cover color of her work, thus enabling her book to be read by men as well as women. Commercial concern and the desire to be popular are attitudes that cannot be encountered in aesthetics.

Aesthetic novels do not attempt to create a religious, moral and ideological change in the reader. When the level of fiction and expression of the Aşk novel is considered, it is understood that the author tries to influence the reader religiously, morally with almost every word that comes out of Şems. 
The language of aesthetic novels is almost perfect. The authors use a symbolic language. Elif Şafak, on the other hand, does not pay much attention to language, as she is concerned about content in her work like popular writers. In the work, which was written in English and then translated into Turkish, the language remains incapable from time to time, the words are used incorrectly, and expressions that do not exist in Turkish are included. All this takes the novel away from aesthetics.

Elif Şafak wants to add value to Aşk by using important people as characters in her novel. Aşk is in the shadow of popularity. As long as the author does not worry about how she is telling as much as what she tells, her works will be doomed to fade away after they shine like a star. 


\title{
1. Giriş
}

\subsection{Popüler Roman}

Popüler kelimesi sıradanlıktan sıyrılan, kendisine benzeyenlerden bir adım öne çıkarak adından söz ettiren şeylere işaret eder. "Popülerin İngilizcede dilsel orijini orta çağlarda 'halkın' (folk bağlamında halkın, people anlamında halkın değil) anlamında kullanımıyla başlar ve günümüzde 'çoğunluk tarafindan sevilen ve seçilen' anlamında kullanılır. Bu bağlamda popüler kültür 'halkın kültürü’ anlamından günümüzde çoğunluk tarafından 'sevilen ve seçilen kültür' anlamına doğru bir dönüşüme uğramıştır." Popüler olan şeyler, yenidir. Eskimeleri hâlinde popülariteleri azalır.

Popüler kültür; geleneksel kültürden beslenen ondan yapı bakımından ayrılan çağdaş kültürdür. Popüler kültür geleneksel kültürden etkilendiği gibi gerektiğinde ideolojilerin kitle iletişim aracılığıyla yayılmasını sağlayan kitle kültüründen de etkilenir. Bu yönüyle popüler kültür; geleneksel kültürle kitle kültürü arasında kalır. "Biçim olarak orta karmaşıklık; aktarımı ya da iletimi, ortam ve teknoloji olarak dolaylı; bilinen bir kaynağı ya da üreticisi vardır; kültürel değerleri ve gelenekleri, yeni formüller biçiminde yansıtır; ürün tüketiciye dönüktür; oldukça ucuza fakat parayla elde edilir." Bu kültür geleneksel değil, popüler olduğundan zamana ve koşula göre değişiklik gösterir.

Popüler sanat; dönemin tanınan kişi ve nesnelerine yer verilerek oluşturulan eserlere verilen addır. Popüler sanata pop sanat da denilir.

\begin{abstract}
“Pop sanatın ilk dönemi sayılan 1953-1958 yıllarında, İngiltere'de endüstriye ilişkin temalar figüratif bir anlayışla işlenmiştir. Pop sanatın en önemli temsilcilerinden Eduardo Paolozzi, imgelerini popüler kültür ve insan endüstri ilişkisinden hareketle biçimlendirmiştir. İnsanmakine ilişkileri üzerinde duran Richard Hamilton ise otomobil ve mekanik ev aletlerini insan imgesiyle birlikte kullanarak kolajlar yapmıştır."
\end{abstract}

Popüler sanat için tüketicinin beklentileri ve istekleri son derece önemlidir. Popüler sanatın en kötü tarafı çok çabuk tüketilip unutulmaya yüz tutulmalarıdır.

Popüler romanlarda aşk, kıskançlık ve ihanet konuları daha çok işlenir. Yazarlar, okuyucunun düşüncelerinden çok duygularını harekete geçirecek nitelikte olay örgüleri meydana getirirler.

Popüler romanlarda, uzun uzun tasvirler yer almaz. Yazarlar, okuyucuyu sıkmayan onların bir çırpıda okuyup bitirecekleri eserler meydana getirirler. Birbirinin devamı niteliğinde olan bu romanlarda mekân adları, kişi adları, yaşanılan zaman ve belki birkaç tesadüf hâriç her şey belli formüllerle oluşturulur. Bu sebeple popüler romanların yazımı estetik romanlar kadar uzun sürmez. Seri üretimi mümkün kılan formüller yaygın şekilde kullanılır. Aşk, polisiye,

1 İrfan Erdoğan ve Korkmaz Alemdar, Popüler Kültür ve İletişim (Ankara: Pozitif Matbaacılık, 2005), 33.

2 Ahmet Oktay, Türkiye'de Popüler Kültür (İstanbul: YKY, 1993), 21.

3 Sanatsal. "Pop Sanatı (Pop Art) Nedir, Ne Demektir?” Erişim 01.03.2019. http://www.sanatsal.gen.tr/pop-sanatipop-art-nedir-ne-demektir/ 
korku türüne örnek olan her eser diğerlerine benzer. ${ }^{4}$ Yazarlar, ömürleri boyunca pek çok eser meydana getirebilirler; fakat onların her biri okuyucu tarafindan sadece bir kez okunur.

Popüler romanların başlıkları ve kapaklarındaki resimler popüler roman okuyucularının ilgisini çekecek mahiyette seçilir. Çoğu zaman "göz alıcı renk ve kompozisyonlarda, romanın kahramanlarını çağrıştıracak 'güzel insanların' resmedildiği ‘Aşkım Izdırabını Dindirecek', 'Yıkılan Umutlar', 'Yaralı Kalp' (...) gibi duygusal isimler”’ taşıdığı görülür. Eser adı ve kapak resmi içerikle bir bağ kuracak mahiyette seçilir. Böylece okuyucu romanı okumadan önce konusu hakkında az çok tahminde bulunabilir.

Popüler yazarlar, kurguda herhangi bir boşluğa yer vermezler. Bu sebeple okuyucu popüler eserleri okurken pasif hâldedir. Bu tarz romanlarda her şey açık şekilde ortaya konulur. "Böyle bir romanın okuyucusundan istediği birikim, orta seviyede okur-yazar olan insanların bildiği, bilmesi gereken şeylerdir." yoksun olduklarını gösterir.

Popüler romanların kişileri tek boyutludur. İyiler hep iyi, kötüler hep kötüdür. Olaylar sırasında duygu ya da düşünce değişimi yaşamazlar. Düz karakter niteliğine sahip olan bu kişiler, "yazarın söylemek istediklerini tek bir darbede ifade edebilmesini kolaylaştıran unsurlardır." $\mathrm{Bu}$ açıdan onlar; duygu, düşünce ve davranış yönünden özgür değillerdir. Onların varlığı tamamen yazara bağlıdır. Romanın başından sonuna değin de yazarın amaçlarına hizmet ederler.

Popüler romanların adlarının duyulmasında medyanın önemli bir payı vardır. Popüler eserlerin reklamı hem sosyal medya hem yayınevi hem de yazarların katıldığı söyleşilerle yapılır. Bu durum son dönemlerde öyle bir hâl almıştır ki okuyucu sanki tanınmış yazarın en son çıkan eserini almazsa büyük bir kayıp yaşayacakmış gibi hissetmeye başlamaktadır.

Popüler romanlar, okuyucuları var olan sıkıntılarına benzer şeyleri başkalarının da yaşadığına inandırabilir. Bu açıdan roman kişisiyle kendileri arasında duygudaşlık meydana getirir. “Bu durumda genç okuyucu 'yeni' ve 'farklı' bir dünyanın hazır kozasını, kendisine sunan romanda hikâye edilen vakanın belirlediği hayat şartlarını, insan ilişkilerini, davranış biçimlerini okumuş, onlardan haberdar olmuş ve netice olarak kendi toplumunun yaşadı ğı yaşamın çeperlerinin dışındaki bu yeni kozanın ölçüleri doğrultusunda değişime başlamış olacaktır." Anlatılarda yer alan kişilerin olaylar karşısında verdikleri tepkilere uyanlara Genç Werther 'in Acıları'nı okuyanlar örnek gösterilebilir. Onların bir kısmı Werther gibi intihar eder.

4 Veli Uğur, 1980 Sonrası Türkiye'de Popüler Roman (İstanbul: Koç Üniversitesi Yayınları, 2013), 26.

5 Yüksel Baypınar, "Türk ve Alman Yığın Edebiyatı -Edebiyat Tarihlerine Alınmayanlar-", Ankara Üniversitesi DTCF Dergisi, 33/ 1-2, (1990), 49.

6 Alpay Doğan Yııldız, Popüler Türk Romanları Kerime Nadir, Esat Mahmut Karakurt, Muazzez Tahsin Berkant 1930-1950 (İstanbul: Dergâh Yayınları, 2009), 60.

7 E. M. Forster, "Düz ve Yuvarlak Karakterler", Roman Teorisi içinde, haz. Philip Stevick. çev. Sevim Kantarcıŏlu (Ankara: Akçağ Yayınları, 2017), 171.

8 Fatih Andı, Roman ve Hayat (İstanbul: Türk Edebiyatı Vakfı Yayınları, 2004), 57. 
Popüler roman yazarları, okuyucuda belli eğilimler oluşturmak için eserlerini kaleme alabilir. Özellikle angaje (ideolojik) romanlar belli tez etrafında oluşturulur. Anlatı boyunca okuyucunun da yazarla aynı fikre sahip olması için romandaki kişiler uğraşıp durur.

\subsection{Estetik Roman}

Estetik, Yunanca aishesis kelimesinden gelir. "Yun. aisthésis= güzel duygusu; Lat. estetica; Fr. esthetique; İng. aesthetic; Alm. aesthetik): Güzelliğin insan aklı ve duyguları üzerindeki etkilerini konu alarak ele alan felsefe dalı." Estetiği bağımsız bir felsefe dalı olarak ilk kez değerlendiren Alexander G. Baumgarten'dir. Onun öncesinde Antik Çă̆' da Sokrates, Platon, Aristoteles gibi düşünürler de estetiği ahlak felsefenin içinde değerlendirip iyi, güzel kavramları üzerinde düşünmüşlerdir.

Estetik varlığı meydana getiren 4 temel öge vardır. Bunlar: estetik süje, estetik obje, estetik değer ve estetik yargıdır. Ontik bütünlük oluşturan bu unsurların birinin eksikliği estetik fenomenin oluşmasına engeldir. Örneğin estetik değer ve yargının oluşmasında estetik obje ve estetik süjenin ilişkisi etkilidir.

Estetik süje; estetik objeyle ilgi içinde olan onu algılayan, kavrayan, ondan haz alarak estetik bir yargıya ulaşan kişilerdir. Estetik süjede; estetik objeye karşı öncelikle duyum daha sonra da alg1 gerçekleşir. Alg1: "Bir şeye dikkati yönelterek o şeyin bilincine varma, idrak"10 anlamına gelir. Estetik süjeye karşı algının meydana gelmesinde özellikle görme ve işitme duyuları etkendir. İnsanlarda bu duyular aracılığıyla tanıma, bilme olguları gerçekleşir. Süje, okuduğu bir roman ya da seyreylediği tarihi bir yapıt karşısında onların ekonomik veya bilgisel yönünü bir kenara bırakırsa 'estetik tutum'dan söz edilebilir. "Estetik tutumun dikkati en çok çeken tarafı faydacı bir tutumdan uzaklaşmasıdır. Sanat eserini sırf ondan aldığımız haz için okumuyorsak; işe başka hesaplar karışıyorsa tutumumuz estetik değildir."11 Estetik süje bu tavrın dışında kalırsa nesneler dünyası; insanda iyi, güzel veya çirkin estetik değerleri oluşturur.

Estetik obje; resim, heykel, şiir vb. sanat yapıtlarına verilen addır. Estetik objeyi dağ, deniz, taş, göl gibi unsurlardan ayıran şey; bir insan tarafından yapılmış olmasıdır. Sanatçı; insanların hâl ve hareketlerinden, doğadaki bir unsurdan yola çıkarak estetik bir eser oluştururken eserine irreal bir yapı da kazandırır.

Estetik obje kişileri etkiler. Aristoteles tragedyanın ereğini nasıl ki katharsiste bulduysa estetik haz da insanları gündelik yaşamın dışına çıkararak onları kuşkularından, kaygılarından arındırır. ${ }^{12} \mathrm{Bu}$, estetik hazzın yenileyici, dönüştürücü bir gücü olduğunu gösterir.

Estetik romanlarda anlatı, popüler romanlardaki gibi somut değildir. Zehra İpşiroğlu'na göre bu romanlar kilitli romanlardır. Yorumlanması bazı şifrelerin çözümlenmesine bağlıdır. ${ }^{13}$

9 Adnan Turani, Sanat Terimleri Sözlüğ̈̈ (İstanbul: Remzi Kitabevi, 1993), 40.

10 Türkçe Sözlük (Ankara: Türk Dil Kurumu Yayınları, 2009), 72.

11 Berna Moran, Edebiyat Kuramları ve Eleştiri (İstanbul: İletişim Yayınları, 2011), 233.

12 İsmail Tunalı, Estetik (İstanbul: Remzi Kitabevi, 2013), 45.

13 Zehra İpşiroğlu, Eleştirinin Eleştirisi (İstanbul: Cem Yayınevi, 1992), 35. 
Okuyucu yazarın ona sunduğu ipuçları doğrultusunda anlatıyı berraklaştırmaya çalışır. Bunu başarabildiği ölçüde eserden haz duyar. Bu durumun gerçekleşmesinde estetik romanlardaki çok anlamlılık etkilidir. Bu sebeple estetik eserlerin anlaşılabilmesi için okuyucunun belli bir bilgi ve kültür seviyesine sahip olması gerekir.

Estetik romanlar defalarca okunabilirler. Onlar her okunduğunda da okuyucuya başka bir anlam dünyasının kapılarını açarlar. Bu yönüyle estetik eserler cevher niteliğindedir.

Estetik olarak nitelendirilen her roman orijinaldir. Bir daha aynısının yazılabilmesi imkânsızdır. "Romanda eskimeyen, romancının ancak romancılık gücüyle yarattığı yeni dünyadır. Bu yeni dünya bir benzeri daha yaratılmadığı için eskimez."14 Edebiyat dünyasında Ahmet Hamdi Tanpınar'ın Huzur'undan; Peyami Safa'nın Yalnızız'ından bir tane daha yoktur.

Estetik roman yazarları, zihin dünyasında oluşturdukları yapıyı eserlerine yerleştirirken ince eleyip sık dokurlar. Uzun düşünmelerinin sonucunda ideolojik ve toplumsal yanı ağır basmayan, estetik tarafıyla dikkat çeken eserler oluştururlar. Onların eserin içeriği kadar biçimini de önemsedikleri eserlerin yapısına, diline, söylemlerine bakılarak anlaşılır. Kusursuza yakın romanların varlığı, kelimelerin tek başına ve bir arada oluşlarıyla yüklemiş oldukları anlamlar okuyucunun estetik duygu yaşamasını sağlar.

Estetik romanlarda yazarın, anlatıdaki kişiler üzerinde herhangi tutumu ya da okuyucuya bir şeyler öğretme, dayatma, hatırlatma gibi amacı yoktur. O; her daim iyi, güzel eser yazmanın peşindedir.

Estetik roman kişileri durağan değildir. Onlar anlatı boyunca duygusal ve düşünsel değişimler yaşarlar. Bu aşamaya gelene dek yaşadıkları buhranlar ayrıntılarıyla eserde yer alır. Yazar; kişileri duygu, düşünce, tavır ve davranışlarında özgür bırakır.

Estetik roman yazarları, adlarını duyurmak ya da ekonomik kazanç elde etmek için eser meydana getirmezler. Onlar, yaşadıkları duygulanmalara okuyucunun da dâhil olması için çaba gösterirler. Estetik eserler, okuyucuyu etki altına alarak onları anlatı üzerine düşünmeye sevk ederler.

Estetik romanlarda tamamlanmamışlık dikkat çeker. İdeal okur, yazarın bile isteye bıraktığı boşlukları yapbozun parçalarını birleştirir gibi tamamlar. "Her sanat yapıtı, zorunluluğun açık ya da üstü örtülü poetikasının ürünü de olsa, sanal olarak sonsuz sayıda okumalar toplamına açıktır. Bu okumaların her biri yapıtta, belirli bir bakış açısına, beğeniye, kişisel bir performansa yeni bir canlılık sağlar." ${ }^{15}$ Böylece yazarın en başta çok anlamlılık oluşturmak için parçaladığ 1 bütünlüğü eseri okuyan her okuyucu kendi anlam dünyasından hareketle bir araya getirir.

Estetik roman yazarları hayatın gerçekliğini birebir eserlerine yansıtmazlar. "Gerçek' in ‘yabancı kılınarak’ bozulması (dönüştürülmesi) ve mantıki özelliğini yitirmesi de, estetik romanların bir özelliğidir."16 Yazarlar, okuyucuyu var olan gerçekliğin dışında kurguladıkları dünyanın içine çekerler. Estetik romanlar diğer romanlar gibi olay merkezli değildir. Yazarlar

14 Kemal Tahir, Notlar/Sanat-edebiyat, haz. Cengiz Yazoğlu (İstanbul: Bağlam Yayıncılık, 1990), 192.

15 Umberto Eco, Açık Yapıt, çev. Pınar Savaş (İstanbul: Can Yayınları, 2001), 34-35.

16 Şaban Sağlık, Popüler Roman Estetik Roman (Ankara: Akçağ Yayınları, 2010), 244. 
için önemli olan bireylerin; iç dünyasını, çatışmalarını anlatmaktır. Bu açıdan söz konusu eserlerde tesadüflere, klişe sözlere, gereksiz tasvirlere yer verilmez. Kişilerin çatışmaları da iç monolog, bilinç akışı gibi tekniklerle ortaya çıkarılır.

Estetik romanlarda metinlerarasılık dikkat çeker. Yazarlar, kendilerinden önce yazılmış dinî, edebî, sosyal metinlerden alıntılar yapabildiği gibi bu metinlere ya da yazarlara göndermelerde de bulunabilirler. Ayrıca metinlerarası ilişkiler müzik, resim, hat vb. sanatlar aracılığıyla da kurulabilir. Bu durum bir yandan yazarların bir yandan da okuyucunun metinlerin birbirleriyle olan ilişkisini çözebilmeleri için belli bir kültür seviyesine ulaşması gerektiğini gösterir.

\section{Elif Şafak ve $\boldsymbol{A s ̧} \boldsymbol{k}$}

Elif Şafak, günümüz romancıları arasında adından sıkça bahsedilen yazarlardan biridir. Aşk'a kadar sırasıyla Pinhan, Şehrin Aynaları, Mahrem, Bit Palas, Araf, Baba ve Piç, Siyah Süt adlı eserleri yayımlar. Her biri de tanınırlığının artmasına katkı sağlar. Fakat onun hem uluslararası başarı ödüllerine layık görülmesinde hem de Türk yayın dünyasında kısa sürede en çok satılan kitabın yazarı olmasında etkili olan $A s ̧ k^{\prime}$ tır. Bu sebeple $A s ̧ k^{\prime}$ ’n diğer eserlerden farklı bir yanı vardır.

Aşk, ilk önce The Forty Rules of Love adıyla yurtdışında daha sonra da Aşk adıyla Türkiye'de yayımlanır. Eserin Türkçeye çevrilmesinde yazara K. Yiğit Us da katkı sağlar. Elif Şafak $A s ̧ k^{\prime}$ ta hem dünyevi hem de tasavvufi aşkı işler. Bir tarafta Ella-Zahara bir tarafta da Mevlana-Şems ilişkisi söz konusu edilir.

Çok kısa sürede satış rekorları kıran, farklı kitap kapağı renkleriyle de piyasaya sürülen $A s ̧ k^{\prime}$ 'n popüler ve estetik romanlardan hangisine dâhil edileceği romanın biçim ve içeriğinin incelenmesiyle mümkündür.

\subsection{Aşk’ın Olay Örgüsü}

\subsection{1. Öykü}

Elif Şafak'ın $A s ̧ k^{17}$ romanında olaylar Ella-Aziz ve Şems-Mevlana arasında gelişir. Ella ve Aziz dünyevi aşkın Şems ve Mevlana ise ilahi aşkın temsilcisi durumundadır. Elif Şafak, Ella ve Aziz arasındaki aşkı romanın ilerleyen sayfalarında tasavvufi bir yönelişin ilk basamağı olarak sayar. Yazar, bu şekilde pek çok okuru etkileyen Şems ve Mevlana hikâyesini ön plana çıkarmaya çalışır. Fakat bunda pek de başarılı olduğu söylenemez. Yüzeysel bir okuma yapıldığında Şems ve Mevlana ilişkisi okuyucuya gerçekliğin kurgulanmış hâli olarak gelebilir. Metnin derinine inildiğindeyse yazar tarafından okuyucuya aktarılmak istenen şeylerin tasavvufi konuların altında gizlendiği görülür. Bu durumu daha iyi görebilmek için birbirinin devamı niteliğinde olan aşk(lar)a bu aşk(lar)ın meydana geliş serüvenine bakmak gerekir.

Ella; aşkın sadece filmlerde, masallarda olacağına inanır. Bu sebeple ona göre evlilikte hoşgörü, şefkat, anlayış ve affedicilik asıl önemli şeylerdir. Üstelik o, 40 yaşına girene dek

17 Elif Şafak, Aşk, çev. K. Yiğit Us, (İstanbul: Doğan Egmont Yayıncılık, 2009). 
tekdüze bir hayat sürer; İngiliz Dili ve Edebiyatını bitirdiği hâlde çalışmaz. Kendini evine, eşine ve 3 çocuğuna adar. Yazar, Ella’yı âdeta evin içine hapsettirir. O, hayatında hiçbir şeye yön veremeyen kocasının kendisini aldatmasına bile göz yummuş acınası bir hâldedir.

Romanda böylesine pasif, mutsuz, can sıkıntısından bunalmış bir kadın olan Ella; eşi David'in telkinleriyle bir anda iş bulur. O, A. Z. Zahara'nın Aşk Şeriatı adlı romanını okuyup ayrıntılı bir rapor yazacaktır. Ella romanı okudukça Aziz'e âşık olur ve değişim, kelimenin tam manasıyla dönüşüm yaşamaya başlar: “Aşk, Ella'nın ömrünün o durgun gölüne gaipten düşüveren bir taş misali indi. Ve onu sarstı, silkeledi, darmadağın etti." "18 Yazar, Ella’nın değişimini eski-şimdi ikilemi arasında verir; olaylar da Ella'nın aşka olan bakışının değişmesiyle şekil alır.

Zahara "modern bir evliya"nın ${ }^{19}$ yansıması olarak romanda kendine yer bulur. Zahara'nın böyle görülmesinde $A$ şk Şeriatı adlı romanında geçen cümlelerinin Ella'nın düşüncelerine bir cevap niteliğinde olması etkilidir: Ella, romanı eline almadan önce kızına aşkın geçici ve cici bir his olduğunu söyler. O, Zahara'nın romanını üstün körü incelerken de "Zira her ne kadar bazıları aksini iddia etse de aşk dediğin bugün var yarın yok cici bir histen ibaret değildir."20 cümlesiyle karşılaşır. Bu, Aşk’ta yer alan kişilerin kendi tercihleriyle oluşmamıştır. Ella'nın kızıyla aşk üzerine aralarında geçen konuşmaların üzerine Zahara'nın kitabında yer alan aşkla ilgili söylemlerin varlığı Elif Şafak’ın kişiler üzerinde oluşturduğu baskıyla ilgilidir. Onlar, bir türlü kendileri olamazlar. Yazar, bir önder gibi onlara söylemek istediği şeyleri tekrar ettirir. Yazarın bu tutumu, okuyucunun ilgisini çekmek için popüler romanlarda sıkça baş gösteren tesadüflere yer verdiğini gösterir. Romanda fark edilen tesadüflerden biri de roman boyunca kimseyle derdini paylaşmayan, kalabalıklar içinde yalnız kalan Ella’nın; -ne hikmetse- kızı Jeannette'nin aşka olan bakışı ve sevdiği adamla evlenmek istemesi yüzünden tartışmaları ve can sıkıntısıyla bu olaydan Zahara'ya bahsetmesiyle ortaya çıkar. Zahara, onu ilahi aşka yönlendirmek için tevekkül etmesini ve teslimiyet göstermesini söyler. Ella, romanda yıllarca Tanrı'nın kapısını çalmayan biri olarak gösterilirken Zahara onun “kurtarıcısı” olur. Bu kadar tesadüf, yazar tarafından olayların akışını etkileyen unsurların oluşması için kullanılsa da okuyucunun popüler romanlardaki yapmacıklığın bir benzerini bu romanda da hissetmesine neden olur.

Zahara, modern dünyada hoş karşılanmayacak bir kadın tipini yakıp yok ederek onun küllerinden yeni bir Ella meydana getirir. İsmi aynı; fakat mizacı, hayata bakışı bambaşka olan bu kadına bakıldığında romandaki boşluk dikkat çeker: Kendisini eşine ve 3 çocuğuna adayan, hiçbir zaman risk almayı bilmeyen, içtiği kahvenin markasını değiştirmek için uzun uzun düşünen ${ }^{21}$ Ella, mizacına hiç uygun olmayarak eşini Zahara’yla aldatır. Böylece kendini büyük bir değişimin içinde bulur ya da yazar tarafından buna zorlanır. Başlangıçta sabit bir kişi

18 Şafak, $A s ̧ k, 14$.

19 Mehmet Tekin, "Tuhaf Bir Tezli Roman: Aşk", Yeni Türk Edebiyatı Araştırmaları, 4, Temmuz-Aralık (2010), 16.

20 Şafak, $A s ̧ k, 31$.

21 Şafak, Aşk, 14. 
olarak tanıtılan Ella'nın yirmi yıllık evliliğini hiçe sayarak romanın ilerleyen kısımlarında eşini Zahara'yla birlikte olmak için terk etmesi okuyucu açısından pek fazla inandırıcı olmaz. Bu durum kabul edilmiş gibi yapılsa bile okuyucu bu sefer de Ella’yı modern dervişle ilahi aşkın kapısını arşınlayacak diye bekler; çünkü Zahara Hristiyan iken aşk aracılığıyla değişmeye başlar ve daha sonra Baba Samed'in etkisiyle Müslümanlığı kabul edip sufi olur. Ella da Zahara'nın tasavvufa olan eğiliminden etkilenir ve ona âşık olur; fakat Ella, Zahara'ya âşık olunca önceki değerlerini kaybeder. Üstelik Zahara da sufiliğe yakışmayan davranışlarda bulunarak Ella’yla fazlasıyla yakınlaşır. Görülüyor ki Elif Şafak ya gerçekten kahramanlarını kendi serüvenlerini yaşamaları için fazlasıyla özgür bırakmış ya da sufiliğin ne demek olduğunu gözden kaçırmıştır. Yazar, her ne kadar hâkim bakış açısıyla Ella-Zahara aşkını oluştursa da elbette ki Zahara'nın bu denli taşkın oluşuna izin vermemelidir. Okuyucunun beklentisinin aksine romanda ilahi aşkın tasavvufi tarafı ne yazık ki Ella ve Zahara cephesinde kendini gösteremez.

Mevlana ve Şems hikâyesinde Elif Şafak'ın "uzun yıllar tasavvufla ilgilenmesinin” 22 etkileri görülür. Yazar, tasavvufi bilgilerini romanın içinde Şems aracılığıyla ortaya çıkarmaya çalışır. Şems, hem Mevlana hem de Kimya ile konuşmalarında onlara Kur'an'ın bâtıni (iç, gizli) anlamlarına yönelmenin önemine vurgu yapar. Mutasavvıfların akıldan ziyade kalp ve ruha önem verişleri de Şems aracılığıyla Mevlana'nın değişiminde etkilidir. Elif Şafak; 40 sayısına hem halk hikâyelerinde hem de İslamiyet'te verilen önemin vurgusunu romanında yaptıktan sonra Şems'in ağzından Gönlü Geniş ve Ruhu Gezgin Sufi Meşreplilerin Kırk Kuralı olarak nitelendirilen kurallar, olay örgüsünün etkisiyle romanda kendine yer bulur. Elif Şafak'ın Aşk'ında yer alan kaynakçada pek çok tasavvufi kitaptan yararlandığg görülür. Roman, bütünüyle kurgudan ibarettir. Elif Şafak, kurmaca bir metinde kaynakçaya yer vererek tasavvufi bilgiye sahip olduğunu okuyucuya ispatlamaya çalışır. Yazarın sözcüsü olan Şems de, karşılaştığı her durum karşısında konuyla kimi zaman ilgili kimi zaman da ilgisiz olmasına rağmen 40 kuraldan birine değinir. Bu, romana belli ölçüde estetiklik de katar; fakat estetiklikten ziyade yazarın ben tasavvufla ilgileniyorum, bunun da etkisiyle roman aracılığıyla söyleyeceklerim var şeklindeki tavrı daha fazla sezilir.

\subsubsection{Anlatıcı ve Bakış Açısı}

Romanlarda anlatılar 1. tekil ben anlatıcı ya da 3. tekil hâkim anlatıcı tarafından okura sunulur. Anlatıcının olduğu yerde onun insana, dine, kültüre, tarihe olan bakış açısı da esere yansır. Bu yönüyle anlatıcı, ben ya da o olarak aktarma işini yaparken taraflı/tarafsız, tasdik edici/ eleştirici, alaycı, parodist (şakacı) ve hicivci olmak gibi bir tutum içine girebilir. ${ }^{23}$ Anlatıcının takındığı bu tutuma 'bakış açısı' denir.

Eserlerde 1. tekil anlatılar, kişilerin ağzından doğrudan aktarılır. Anlatıcı; gördüklerini, duyduklarını, hissettiklerini, düşündüklerini, tahminlerini ortaya koyar. Onun bilgisi kendisi

22 CNN TÜRK. "Elif Şafak’ın Tasavvufa Olan İlgisi Nereden Geliyor?” Erişim 01.03.2019. https://www.cnnturk. com/video/2012/07/18/soru-cevap/biyografi/elif-safak-in-tasavvufa olan-ilgisi-nereden-geliyor/index.html

23 Gürsel Aytaç, Çăgdaş Türk Romanları Üzerine Incelemeler (Ankara: Gündoğan Yayınları 1990), 26. 
dışında oldukça sınırlıdır; fakat 1. tekil anlatılar, okur için daha inandırıcı daha samimidir. Aşk romanında Şems-Mevlana hikâyesi çoğul anlatıcıyla okura sunulur. Romanın bu kısmında Şems, Rumi, Çömez, Alaaddin, Baybars, Baba Zaman, Çöl Gülü, Mutaassıp, Talebe Hüsam, Kerra, Sultan Veled, Süleyman, Kimya, Şeyh Yasin ve Katil olayları kendi bakış açılarıyla aktarırlar. Çoğul bakış açısının uygulanmasıyla çevreyi, olayları kendilerinin algılayışlarıyla yansıtan kişiler romana çok sesli, renkli ve derinlikli bir boyut kazandırır. ${ }^{24} A s ̧ k$ 'ta çoğul anlatıcının kullanılması bir yandan okuyucunun herkesi yakından tanımasına vesile olurken bir yandan da romana estetik bir hava katmış gibidir. Okuyucu; görünürde olaylara, kişilere, mekâna farklı kişilerin perspektifinden bakma zenginliğine kavuşur. Elif Şafak, 13. yüzyılda Mevlana ve Şems arasında geçen olayları tarihi gerçeklikten hareketle romanında işler. Yazar, çoğul bakış açısını kullanarak oluşturduğu bu bölümde herkese söz hakkı vererek bir nevi üzerine düşen sorumluluğu da anlatıcılara yükler. $A$ şk'ta Mevlana'nın Şems'le tanışmadan önceki hâlinden sadece birkaç cümleyle bahsedilir. Esasen Mevlana'nın Şems'le tanıştıktan sonra yaşadığ 1 değişimin; ailesine, çevresine, dine bakışında kendini gösterdiği de kişilerin ifadeleriyle ortaya çıkar. Yukarıda adı geçenler, güya Mevlana ve Şems ilişkisini kendi bakış açılarıyla vererek eseri çok katmanlı bir hâle dönüştürür. Bu şekilde okuyucu her anlatıcıda farklı bir ayrıntı farklı bir renk hatta onların konuşma biçimlerindeki etkiyle farklı bir tat bulacağına inandırılır.

A. Z. Zahara'nın yazmış olduğu Aşk Şeriatı adlı eserle açılan Mevlana-Şems kapısının ardında işlenmeye çalışılan tasavvuf ne yazık ki çoklu bakış açısıyla da tam olarak aktarılamaz; çünkü sözü farklı kişilere emanet eden yazar, bu durumu unuturcasına etkin olmaya çalışır. Yazarın bir röportajında “Aşk bizi tamamlayacak olan yegâne öz. Bence aşk bir milat. Hani 'aşktan önce', bir de 'aşktan sonra'. Eğer 'Âşık oldum ama hâlâ aynı insanım' diyorsak orada bir sorun var. Âşık olmuşsak aynı insan olamayız artık." ${ }^{25}$ demesiyle Şems'in "aşktan önce ve aşktan sonra aynı insan olarak kalmışsak yeterince sevmemişiz demektir." ${ }^{26}$ sözü arasında hiçbir fark yoktur. Şafak, bu yaklaşımıyla âdeta eserdeki anlatıcıları, kendi düşüncelerini okuyucuya aktarabilmek için kullanır.

Elif Şafak her şeyden önce Ella-A. Z. Zahara ve Mevlana-Şems arasında geçen olaylarla ilahi aşkın önemine vurgu yapmaya çalışsa da vermek istediği mesajlar nedeniyle anlatıcıları bir türlü kendi hâline bırakamamıştır. Bu durum çoklu bakış açısı gibi modern bir yöntemi kullanan yazarın başarısını engellemiştir. Ella'nın Mevlana'nın ikinci eşi Kerra'dan ya da manevi kızı Kimya'dan farkı yoktur. Hepsi kadın olmanın kendilerini erkeklerden geri planda bıraktığını roman boyunca söyler durur. Kimya'nın kadın olduğu için okula gidemeyeceği, Kerra'nın kadın olduğu için Şems ve Mevlana'nın istişarelerine katılamadığı ve mutfak merkezli bir hayat içine sürüklendiği, Ella'nın ise kırklı yaşlara değin tekdüze giden hayatında yine

24 Mehmet Tekin, Roman Sanatı Romanin Unsurları 1 (İstanbul: Ötüken Neşriyat, 2010), 58.

25 ElifŞafak.us. "Aşkı Bulmak İçin”, Erişim 02.03.2019. http://www.elifsafak.us/roportajlar.asp? islem=roportaj\&id $=290$

26 Şafak, $A$ şk, 339. 
Kerra gibi mutfak merkezli yaşadığı, eşinin ve çocuklarının gölgesinde her gün aynı şeyleri yaparak gününü geçirdiği okuyucu tarafından gözlemlenir. Şems bir sufi olmasına rağmen roman boyunca hem Kimya'ya hem de Kerra'ya yakın davranışlarda bulunur. Mehmet Tekin; Şems' in sergilediği davranışlardan dolayı onun sanki alelade bir evde yetişmiş ya da sevgilisini bekleyen onunla cilveleşen bir yavuklu hâline getirilmeye çalışıldığına dikkat çeker ${ }^{27}$. Kişilerin bulundukları ortama, zamana ve durumlarına yakışmayacak hareketler sergilemeleri roman boyunca hem kendi ağızlarından hem de başkalarının onlara bakışlarıyla bir bir verilir. " $\mathrm{Bu}$ açıdan aceleye gelmiş, ihmale uğramış bir romandır $A s ̧ k$; dolayısıyla arızalıdır, eksiklidir..."28 Dikkatli okuyucuların gözlerinden bu detay elbette kaçmaz.

Eserlerde hâkim/tanrısal bakış açılı 3. tekil anlatıcı; kişilerin geçmişlerini, yaşadıkları ânı, hatta onların gelecekte neler yaşayacaklarını bilir. Anlatıcı, roman kişilerine üsten baktığı için dikkatinden hiçbir şey kaçmaz; isterse kişilerin iç dünyalarını da yansıtır. Böylece anlatılarda hiçbir şey gizli kalmaz. Her şey ve herkes şeffaf bir hâlde okuyucunun karşısında yer alır. Elif Şafak'ın bu romanında da Ella-Aziz hikâyesi hâkim ya da tanrısal anlatıcıyla okura sunulur. Anlatıda özellikle Ella'nın iç dünyasında yaşadığı çatışmalar, zihninden geçen düşünceler anlatıcının sahip olduğu özellikler sayesinde yüzeysel de olsa ortaya çıkarılmaya çalışılır. Ella’nın kendini sorguladığı şu sözleri tanrısal bakış açısının sonucudur:

"Ella hafifçe kıpırdayıp omuzlarını dikleştirdi. Zoraki, iğreti bir tebessüm kondu dudaklarına. Bir yandan da merak ediyordu, acaba kocası niye bu kadar çırpınıyordu? Bunca sene onu meslek sahibi olmaktan alıkoyduğu için birdenbire senelerin kaybını telafi etmeye mi çalışıyordu? Yoksa onu aldattığı için pişmanlık duyup bu şekilde arayı yumuşatmayı mı umuyordu? Hangisi doğruydu acaba?’29

Yine romanda 3. tekil anlatıcının anlatıdaki her şeyi en baştan bildiği, Ella'nın hiç ummadığı bir anda A. Z. Zahara adlı yazara âşık oluşunun “Aşk, Ella'nın ömrünün o durgun gölüne gaipten düşüveren bir taş misali indi. Ve onu sarstı, silkeledi, darmadağın etti." ${ }^{30}$ şeklinde verilmesiyle kendini gösterir. Böylece $A s ̧ k^{\prime}$ ’n sonunun baştan hissettirilmesi onu estetiklikten uzaklaştırır.

\subsubsection{Kişiler}

Anlatılarda kişiler; birinci derecede kişiler, ikinci derecede kişiler ve figüran olarak karşımıza çıkar. Aşk'ta birinci derecede kişiler Ella, A. Z. Zahara, Mevlana ve Şems; ikinci derecede kişiler David, Jeannette, Baba Zaman, Kerra, Kimya, Çöl Gülü; diğer kişiler ise figüran olarak yer alır. "Eğer bir karakter, inandırıcı bir şekilde bizi şaşırtabiliyorsa, ona 'yuvarlak' karakter

27 Tekin, "Tuhaf Bir Tezli Roman: Așk", 32.

28 Mehmet Tekin, “Aşk Romanında Anlatıcının Halleri”, Yeni Türk Edebiyatı, 2, (2010), 115.

29 Şafak, $A s ̧ k, 17$.

30 Şafak, Aşk, 14. 
diyebiliriz. ${ }^{\prime 31} A s ̧ k$ 'ta birinci derecede kişiler yuvarlaktır. Elif Şafak’ın Mevlana ve Şems aşkını ön plana almak yerine Ella ve Zahara'nın aşklarını öne çıkarmasından hareketle aşağıda Ella ve Zahara'nın kişiliklerine yer verilirken; Kimya ve Şems'e ise fantastik nitelikte özellikler taşımalarından dolayı yer verilmiştir.

Yazar, roman boyunca özellikle Ella'nın değişimini ön plana çıkarır. Ella'nın fiziki tasvirinden ziyade yaşadığı değişim Elif Şafak tarafından önemsenir. Ella, eski-şimdi ikileminde roman boyunca değişim yaşayan kendinden beklenmeyecek davranışlar sergileyen kişilerden biridir. Başlangıçta kendini evine, kocasına ve çocuklarına adayan bu kadın A. Z. Zahara'yla tanıştıktan sonra silik bir tip olmaktan sıyrılarak özgürlüğün doruğuna ulaşır. Eşini ve çocuklarını bırakarak sevgilisiyle başka bir ülkede aşk yaşar. Geride bıraktıklarını düşünmeden geçen zamanın ardından yine de çocuklarıyla bir arada yaşamayı düşünmez. Romanda Ella'nın hayatının Zahara'nın ölümünün ardından planlama yapmadan anı yaşayarak geçeceği okuyucuya sezdirilir.

Zahara'nın fiziki özellikleri Ella'ya gönderdiği fotoğrafla açığa çıkar. "Uzakdoğu'da bir yerlerde çekilmiş gibiydi fotoğraf; ... İnce uzun burnu, sert hatları, ama bir o kadar yumuşak ve şefkatli bir ifadesi vardı. Elmacık kemikleri çıkık, alnı genişti; uzun kara saçları dalga dalga omuzlarına dökülmekteydi. Gözleri durgun bir yeşildi. ${ }^{\prime 32} \mathrm{Bu}$, modern romanlarda pek rastlanmayan fiziki tasvir oluşturma tekniğidir.

Zahara da Ella gibi değişim yaşayan kişilerdendir. O, Ella'ya hayatını anlatırken s-u-f-i harflerine uygun yaşama nasıl kavuştuğundan uzun uzun bahseder. Zahara; Margot adlı kendinden yaşça büyük kadına olan aşkıyla değişim yaşamaya başlar. Sevdiği kadının ölümüyle de "Hızla değiştim, çirkinleştim, çirkefleştim ve en nihayetinde dibe vurdum." kendindeki değişimin farkında olduğunu ortaya çıkarır. Önceleri esrar kullanan, anı yaşamayı seven, tek gecelik ilişkilerin kahramanı olan Zahara, Mekke ve Medine'ye giren ilk Hristiyan fotoğrafçı olmayı hayal ederken sufilerin yanında Müslüman olup modern bir derviş hâlini alır.

Elif Şafak, popüler romanlardaki tasvir yoğunluğunu okuyucuyu sıkmamak adına en aza indirir; onları yaşadıkları değişimle ön plana çıkarmaya çalışır. Yazar bunu yaparken estetik romanlarda görülen kişilerin psikolojik ve bilinçaltına yönelik anlatımlarını göz ardı ettiği için eserini ne estetik ne de popüler nitelikte bir anlayışa kavuşturur; çünkü Elif Şafak, Zahara ve Ella'nın çatışmalarını tam manasıyla veremez. Romanda her ikisinin de bunalımları yazar tarafından yüzeysel olarak geçiştirilir.

Estetik romanlarda görülebilen fantastik kişilere $A s ̧ k$ romanında da rastlanır. Eserde Kimya ölülerle konuşabilirken, Şems duvarın ardında olup bitenleri görebilir. Elif Şafak, estetik hâle dönüştürmeye çalıştığı bu kişilerin roman boyunca kendilerine özgü yeteneklerini kullanmaları için onlara belli olanaklar sağlar. Kimya ölülerle konuşabildiği için Mevlana’nın yanında talebe olur; Şems ise duvarların ardını görmesi ve gerektiğinde kendini görünmez yaptığından dolayı

31 E. M. Forster, "Düz ve Yuvarlak Karakterler", Roman Teorisi, haz. Philip Stevick, çev. Sevim Kantarcıoğlu (Ankara: Akçă̆ Yayınları, 2017), 176.

32 Şafak, Aşk, 233.

33 Şafak, Aşk, 265. 
çevresindekileri etkiler. Örneğin; Mevlana, Şems'le çok fazla ilgilendiği için Alaaddin'in kendisine duyduğu öfkeyi önce Şems aracılığıyla daha sonra da Alaaddin'in ağzından duyar. Mevlana bu şekilde Şems’in "fantastik nitelik”teki kerametine tanıklık eder.

\subsubsection{Zaman}

Popüler romanlarda zaman, kişilerin üzerinde etkili olan olaylarda uzun bir süreyi kapsar. Yazarlar, gereksiz ayrıntıları zaman özetleme ya da zaman atlama tekniklerini kullanarak en aza indirir. Aşk'ta iki ayrı zamandan bahsedilmesi dikkat çeker. Bir yanda Ella ve Zahara aşkının yaşandığı zaman; bir yanda da 13. yüzyıl coğrafyasının anlatıldığı zaman dilimi vardır. Her iki zaman da uzun süreyi kapsar. Yazar, eserinde geçmişle şimdiyi birlikte vermeye çalışır; bunda da belli ölçüde başarı sağlar. Aşk'ta roman kişilerinin zamanlarının ruhuna uymayan davranışlar sergiledikleri bir yana bırakılırsa, asırlar önceki bir zaman diliminin “şimdi”"nin içinde eritilmesi okurda bir estetik zevk uyandırır; fakat 13. yüzyılda geçen olaylarda bizi o zamanın anlatıldığına inandıran tek gerçeklik Mevlana ve Şems ilişkisine yer verilmesidir. Yazar, o zamanın kendine has ruhsal atmosferini roman boyunca okuyucuya hissettiremez. $A s ̧ k^{\prime}$ ta zaman kronolojik sıraya göre ilerlemez, geri ve ileri kırılma teknikleri de kullanılır.

Aşk’ta yaşanılan anın önemli olduğuna sıklıkla değinilir: Şems; Çöl Gülü’nün içinde bulunduğu mekânı terk etmesi hâlinde kirlerinden de kurtulacağını bildiğinden ona "Mazi bir girdaptır. Fark ettirmeden seni içine çeker. Hâlbuki sana lazım olan bir tek şu andır. Şu anın hakikatini yaşamaktır aslolan" ${ }^{34}$ der. Şems'in anlatı boyunca bahsettiği 40 kuraldan 28. olanı da içinde bulunulan anın önemini vurgulamak için oluşturulmuştur: "Kural Yirmi Sekiz: Geçmiş, zihinlerimizi kaplayan bir sis bulutundan ibaret. Gelecek ise başlı başına bir hayal perdesi. Ne geleceğimizi bilebilir, ne geçmişimizi değiştirebiliriz. Sufi daima şu an'ın hakikatini yaşar." ${ }^{35}$ Yine roman boyunca Ella'dan eski-şimdi çatışması verilerek bahsedilir: "Eskiden, evliliklerine zeval gelmesin diye suları bulandırmaz, bilmezden gelir, dünyadan haberi yokmuş gibi davranırdı. Şimdiyse olanı biteni bildiğini ama umursamadığını anlatıyordu bu hareketiyle." ${ }^{36}$ Ella'nın "yaşadığı an"a olan tutkusu, romanda geçen bu ifadelerle daha da somutlaşır. Ella, sevgilisi öldükten sonra geçmişe bakıp üzülmediği gibi geleceği de planlamaz. $\mathrm{O}$, anı yaşamanın peşindedir.

“An”a verilen önem daha çok estetik eserlerde karşımıza çıkar. Bu konuda İhsan Turgut estetik romanlarda 'şu an'ın çok önemli olduğunu, yazarların ‘an'a önem verişlerinin sebebinin kendilerinin varoluş mücadelesi vermelerinden kaynaklandığını söyler. ${ }^{37} A$ şk'ta zaman kullanımına estetik bir görünüm kazandırılmaya çalışılmışsa da bunda tam olarak başarılı olunduğu söylenemez. Çünkü estetik romanlarda "zaman/an” kavramları romanın birer unsuru gibi ele alınıp derinlemesine işlenmesine, roman kişilerinin çizilmesinde önemli bir

34 Şafak, $A s ̧ k, 177$.

35 Şafak, Aş̧, 267.

36 Şafak, Aşk, 224.

37 İhsan Turgut, Sanat Felsefesi (İzmir: Bilgehan Matbaası, 1991), 88. 
rol oynamasına rağmen $A s ̧ k$ 'ta sadece tasavvufi manada bir “an” kavramı öne çıkarılmıştır. Dolayısıyla romandaki işleniş şekliyle "an” ya da "zaman”ın Ella veya Zahara, Şems veya Mevlânâ'nın roman karakteri olarak çizimlerinde, onların varlıklarını ortaya koymalarında herhangi bir katkısı/etkisi olmadığ 1 görülmektedir. Bu sebeple de $A s ̧ k$, "zaman”ı estetik boyutuyla değerlendirememiş, daha çok popüler romanlara yaklaşmıştır.

\subsubsection{Mekân}

Aşk'ta mekân oldukça geniştir. Mekânların bir kısmı sadece olayların genişlemesinde bir kısmı da romandaki kırılmaların meydana gelmesinde etkilidir. Yazar romanda hem beşerî hem de tasavvufi bir aşkı işleyerek yerel olmak yerine tüm insanları ilgilendiren bir konuyu tercih etmiştir. Benzer bir tercih yazarın mekân tercihinde de hissedilmektedir. Şöyle ki romanda işlenen mekânlar neredeyse dünyanın dört bir yanına dağıtılmış, Amerika, Avrupa, Asya ve Afrika' dan farklı şehirler romana dâhil edilmiştir. Romanın önce İngilizce yazıldığı da düşünüldügüunde böylesine geniş bir mekân tercihinin altında farklı ülkelerdeki insanların kendi bölgelerinde geçen bir romanı okudukları intibaını uyandırmak endişesi taşındığı hissedilmektedir.

Romanda yer alan diğer öğelerde olduğu gibi mekân tasvirinde de estetik bir bakış açısının tam olarak yakalanamadığı görülmektedir. Eserde mekân tasvirleri yazar tarafından en aza indirilir. Mesela Ella okura tanıtılırken yaşadığı evin/mekânın ayrıntılarına fazla girilmez. Ella’nın yaşadığı şehir/mahalle/evin tasvirindense gününü evde geçiren, kendini kocasına ve çocuklarına adayan, mutfaktan hiç çıkmayan kadının bunalımları kısmen de olsa verilmeye çalışılır. Yazar için önemli olan mekânı okuyucunun gözünde canlandırmak değil; mekânın kişilerin psiko-sosyal durumunu ifşa etmesidir.

Ella Amerika'da Northampton'da, krem rengi Victorya tarzı kocaman bir evde yaşar. Evin beş yatak odası, üç arabalık garajı ve bahçesinde jakuzisi vardır. ${ }^{38}$ Yazar, evden kısaca bahsettikten sonra mekânla Ella arasındaki bağı göstermeye başlar. Ella gününü evde geçirir, kendini kocasına ve çocuklarına adar, mutfaktan hiç çıkmaz. Hayatına yön veren yegâne pusula evi ve evliliğidir. ${ }^{39} \mathrm{Ev}$, eşinin ve çocuklarının o mekânda yer almalarından dolayı Ella’nın kendi duygu ve düşüncelerine göre yaşamasına engeldir. Elif Şafak, Ella’nın Aziz Zahara'ya e-posta attığı ilk gün evin mutfağının 'süklüm püklüm'40 olduğunu vurgular. Ella, süklüm püklüm bir mutfakta e-postayı konuşacak, derin sohbetler edecek birine ihtiyaç duyduğu için atar. Ailesi yanında olsa da o, yalnızdır. Mutfağın, tek bir kelimeyle süklüm püklüm olarak tasvir edilmesi yazarın mekândansa kişilerin psiko-sosyal durumunu ifşa etmek istediğini göstermektedir. Mutfağın var olan durumu Ella'nın yaşadığı ruhsal bunalımlarla örtüşmektedir.

Ella ve Zahara aşkının ilahi bir aşk görünümünde olmasını isteyen yazar, Zahara'nın sözde sufi oluşunu da kullanarak onları Konya'da buluşturur. Bu noktada yazarın zoraki bir mekân tercihi yaptığı da düşünülebilir. Sözde sufi Zahara'nın, tasavvufa olan eğiliminin inandırıcılığı

38 Şafak, Aşk, 13.

39 Şafak, Aşk, 12.

40 Şafak, Aşk, 69. 
için son nefesini Konya'da vermek istemesinden daha doğal bir şey yok gibidir. 13. yüzyılda geçen tarihi bir gerçekliğin Mevlana-Şems hikâyesinin de elbette ki geçeceği mekân Konya'dır. Yazar, mekânın kişinin yaşam felsefesine, dinine, diğer insanlara olan davranışlarına etkisini Mevlana-Şems hikâyesi aracılığıyla ortaya çıkarmaya çalışır. Kimya Konya’ya geldiğinde dinî anlamda kendini geliştirir, Çöl Gülü Konya' da genelevden kaçışıyla sufi olur, Zahara bulunduğu mekânı terk edip sufilerle tanıştıktan sonra değişir, Ella ise Konya'ya geldikten sonra "Sabah ezanının ürperticiliğini”’41 hisseder. Tüm bunlar, Elif Şafak’ın $A s ̧ k$ 'ta estetik romanlara özgü bir mekân oluşturmaya çalıştığını gösterir; fakat kişi-mekân arasındaki ilişki eserde bir türlü estetik romanlara özgü niteliğe ulaşamaz. Estetik romanlarda mekânla kurgu arasında bütünlük vardır. Aşk' ın kurgusunda yer alan zaaflar buna engeldir. Yazar, tasavvufi aşkı anlatmak için kendisine sufi denilemeyecek hareketlerde bulunan Zahara’yı Konya'ya gitmesi için âdeta zorlar. Genelevde çalışan bir kişi sadece Konya'da olduğu için mi sufi olur? Ella, Konya'da değil de bir başka şehirde olsaydı sabah ezanı ona ürpertici gelmeyecek miydi? Bu sorular, Elif Şafak'ın tasavvufu sadece Konya'yla bağdaştırmasından kaynaklanır. Bu yüzden $A s ̧ k$ 'ın mekânlarında estetik yapı kendini tam manasıyla gösteremez. Yine de yazarın, geleneksel romanlarda yer alan mekân tasvirlerinden uzaklaşarak estetik romanlara yaklaştığı, Şems ve Mevlana hariç manevi anlamda değişim yaşayan kişilerin durumunu vermek için Konya'yı tercih ettiği gözden kaçırılmamalıdır. Elif Şafak popüler romanlarda dikkat çeken eşya, dekor tasvirine yer vermediğinden $A s ̧ k^{\prime}$ ta estetik romanlardaki mekân-insan ilişkisine yaklaştığı söylenebilir.

\section{Biçimsel Yapı}

Mevlana ve Şems ilişkisine bakıldığında okuyucuda romanın bu kısmının bir zorlama neticesinde oluştuğu hissi uyanmaktadır. Bilindiği üzere 2007 yılı Mevlana’nın doğumunun 800. yılıdır. Bu sebeple 2007 yılı Unesco tarafindan "Mevlana Yılı” olarak kabul edilmiştir. Elif Şafak'ın $A s ̧ k^{\prime}{ }_{1}$ '1,5 yılda yazmış olduğu ${ }^{42}$ da düşünüldüğünde yazarın 2008 yılında bu romanı yazmaya başladığı anlaşılır. Böylelikle, Mevlana'nın fazlasıyla konuşulduğu yıllarda Elif Şafak hem yurtdışında hem de yurtiçinde ilgi çekecek bir gerçekliği -Mevlana-Şems ilişkisini- $A$ şk'ta işleyerek kitabını normalden daha fazla okunur hâle getirir. Bu yönüyle roman, kurgusunda var olan tesadüfler kadar ortaya çıkış serüveni ile de dikkat çekmektedir.

Elif Şafak’ın Aşk kitabının kapağında büyük bir kalp ve kalbin içinde damarların olduğu resim vardır. Bu, kapağı inceleyenlere hem kalbi damarların beslediğini hem de bir ağacın yapraklarının fillizlenip çoğalmasını hatırlatır. Aşk’ın birleştirici bir gücü olduğunu roman boyunca vurgulayan yazar, görülüyor ki bu düşüncesini kitabın kapağında da göstermeye çalışır.

$A s ̧ k$, Mart 2009 yılında ilk olarak pembe kapaklı daha sonra gri (kül rengi) kapaklı olarak çıkmaya başlar. Pembe kapağın daha çok bayanlarla özdeşleştirilmesinden dolayı ${ }^{43}$ yazar,

41 Şafak, $A s ̧ k, 309$.

42 Youtube. "Elif Şafak-Samanyolu TV Kum Saati Programı", Erişim 02.03.2019. https://youtu.be/ChlTcmnTnhs

43 Youtube. "Elif Şafak-Haber Türk Saba Tümer'le Bu Gece Programı”, Erişim 02.03.2019. https://www.youtube. com/watch?v=P-OsUB4UL6A 
kitabının sonraki baskılarının bir kısmını gri (kül rengi) kapaklı olarak tercih eder. Böylece erkek okuyucuların bazılarında görülen, pembe kapaklı bir kitabı satın almama ya da toplum içinde okuyamama durumu ortadan kalkmış olur. ${ }^{44}$ Bu baskıdan sonra Elif Şafak’ın kitabının satışı da artar. "Popüler romanlar okuyucunun isteklerine göre şekillenip onların isteklerine yanıt verdiğinden bir tüketim aracı olarak görülür." ${ }^{45} A s ̧ k$ ' 1 tüketici-eser ilişkisine dâhil olduğu, okuyucunun isteği doğrultusunda renginin değiştirilmesiyle ortaya çıkmış olur.

Elif Şafak'ın popülaritesi arttıkça yayınevleri de onun isteklerini gerçekleştirmeye çalışır. Yazar, $A s ̧ k^{\prime}$ ta kendi tasavvufi bilgilerinden yola çıkarak sufilikle ilgili oluşturduğu 40 kuralı Şems aracılığıyla dile getirir. Eserde yer alan bu kurallar okuyucu tarafindan fazlasıyla beğenilip dilden dile dolaşır. Elif Şafak da $A s ̧ k$ 'ta yer alan 40 kuralı, alt alta yazarak Aşkın Kırk Kuralı adıyla ayrı bir kitap olarak piyasa çıkarmıştır. Üstelik bu durum kitabın satışının yapıldığı internet sitelerinin bültenlerinde hemen hemen aynı ifadelerle "Elif Şafak'ın yayıncılığımızda bir fenomen olan, 1 milyona yakın satan romanı Aşk'ın en çok sevilen, en çok paylaşılan bölümü Aşkın Kırk Kuralı kitap oldu..."46 denilerek okuyuculara ilan edilir.

Popüler romanların özelliklerinden biri olan geniş çevrelerce tanınma da $A s ̧ k$ 'ta kendini gösterir. Elif Şafak, Aşk'ı önce İngilizce sonra da Türkçe olarak yayımlar. Romanda Yahudi olan Ella'nın sonradan Müslüman olan A. Z. Zahara ile olan aşkının anlatılışı ülkemizde olduğu kadar yurtdışında da son derece dikkat çeker. Romanda Ayşe ile Mehmet'in aşkı ya da iki Müslüman arasında aşkın işlenmeyişi elbette basit bir tercihten kaynaklanmaz. Yazar, Aşk'la bir taraftan Doğu bir taraftan da Batı dünyasının ilgisini çekmek ister. Elif Şafak'ın, Mevlana ve Şems'in anlatıldığı Aşk Şeriat'ında tasavvufu işlemesi hem onun hem de eserinin ülke sınırını aşan bir üne kavuşmasında etkili olmuştur.

Yazar, bilinçli şekilde kurguladığı eserinde; çeşitli söyleşilere katılarak eserini de reklam konusunu yapmayı başarır. Estetik bir eser ortaya koyan hiçbir yazar bu zamana dek onun kadar göz önünde bulunmamıştır. Katıldığı hemen her programda anlatmak istediğinin "aşkın birleştiriciliği”" olduğunu, yıllardır tasavvufla ilgilenmesinin kendisinde oluşturduğu etkiyle de Mevlana ve Şems arasındaki ilişkiyi anlattığını söyleyen yazar, eserinin dünyevi duygularla örülü olduğunu gözden kaçırmış olmalıdır. “Elif Şafak’ın bugünkü şöhretini kazanmasında ve kişisel markalaşma sürecinde önemli bir yere sahip olduğu gözlemlenen internetten pazarlamanın ise yayınevinin yönlendirmeleriyle gerçekleşen bir pazarlama stratejisi olduğu söylenebilir." ${ }^{47}$ Elif Şafak, sosyal medya kanallarını da kullanarak adının unutulmaması için dikkat çekici bir çaba gösterir.

44 Milliyet. "Maçolar için “AŞK”"ın gri kapaklısı çıktı.” Erişim 02.03.2019. http://www.milliyet.com.tr/pembekapak-delikanliyi-bozdu---ask-grioldu/pazar/haberdetay/28.06.2009/1111421/default.htm

45 Selami Çakmakçı, Popüler Roman ve Muazzez Tahsin Berkand, (Doktora Tezi, Fırat Üniversitesi 2012), 18.

46 Kitapyurdu. "Aşkın Kırk Kuralı." Erişim 02.03.2019. https://www.kitapyurdu.com/kitap/askin-kirk kurali/490917. $\mathrm{html}$ ?gclid=EAIaIQobChMIxffSIN2b4QIVFobVCh1A1APREAYYAyABEgLVrPD_BE

47 Belma Canbay, Türkiye'de Roman Yazarlarının Markalaşma Süreci: Elif Şafak Örneği (Yüksek Lisans Tezi, Ankara Üniversitesi 2014), 248. 


\subsection{Kurgu ve Anlatım Seviyesi}

Elif Şafak, romanın kurgusunu asıl hikâyenin içine yerleştirilmiş çerçeve hikâyelerle sağlar. Yazar, daha çok Doğu metinlerinde karşılaşılan bu yöntemi okuyucuyu romanın içine çekebilmek için kullanır. Görünürde asıl hikâye ilahi aşkın işlenişinden dolayı Mevlana-Şems ilişkisinin anlatıldığı kısımken; Ella ve Zahara arasındaki aşk, yazar tarafından daha fazla ön plana çıkarılır. Mevlana ve Şems ilişkisinin anlatıldığı yerlerde Şems'in etkisiyle de iç içe geçen her olayın sonucunda okuyucuda ders mahiyeti oluşturacak farklı küçük hikâyelere de yer verilir. Bu, $A$ şk’’ estetiklikten uzaklaştırır; çünkü estetik romanlar, okuyucuda dinî, ahlaki, ideolojik bir değişim oluşturmaya çalışmaz. Oysaki Şems'in ağzından çıkan hemen hemen her söz, okuyucuyu dinî, ahlaki açıdan tesir altına almak için oluşturulmuştur.

\subsection{Anlatım Teknikleri}

Eserlerde farklı anlatım tekniklerine yer verilmesi anlatının tekdüzeliğini ortadan kaldırır. Elif Şafak, $A s ̧ k^{\prime}$ ta; mektup, e-mail, geriye dönüş ve montaj tekniklerini kullanmıştır. Bu anlatım teknikleri sayesinde $A s ̧ k^{\prime}$ 'n okuyucuyu farklı ama popüler bir kurgunun içine çekmeye çalıştığı görülür. "Popüler romanlar, anlatım teknikleri yönünden oldukça zengindir. $\mathrm{Bu}$ anlatım tekniklerinin en büyük işlevi, romanda geçen bazı olaylara açıklık getirmeleridir. Mesela, romandaki olayda 'bir düğüm' olarak yer alan 'Acaba ne olacak?' veya 'Daha sonra ne olacak?' gibi soruların cevapları bu metin türlerinde (gazete haberlerinde, mektupta, hatırada vs.) verilir."48 Elif Şafak, eserinde kullandığı anlatım teknikleriyle kurgusunu tekdüzelikten kurtarır. Okuyucu, geriye dönüş tekniğiyle kafasındaki sorulara cevap bulur; iç monolog tekniğiyle Ella'nın çatışmalarına; mektup tekniğiyle de Ella-Zahara aşkına şahitlik eder.

Elif Şafak, popüler romanlarda karşılaşılan anlatım tekniklerine daha çok estetik romanlarda görülen montajı da dâhil eder. Montaj, metinlerarasılığın alt koludur. Yazarlar, eserlerini derinleştirmek, güzelleştirmek için bu tekniği kullanırlar. Aşk'ta ise Elif Şafak'ın montaj tekniğini böyle bir amaç için kullanmadığı ortadadır. Şafak, tasavvufi bilgisini çoğunlukla kıssalar ya da Kur'an'daki sureler aracılığıyla vermeye çalışsa da bu bilgiler eserde yavan kalır. Çünkü yukarıda da değinildiği gibi yazarın derdi Mevlana ve Şems aşkını ön plana alarak tasavvufi bir eser ortaya çıkarmak değildir. Şafak, Mevlana ve Şems'e âdeta eserine dikkat çekebilmek için yer verir. Bu sebeple $A s ̧ k$ 'ta kullanılan anlatım teknikleri estetiklikten uzaktır.

\subsection{Dil ve Üslup}

Estetik romanlarda yazarların dili kusursuza yakındır. Onlar, eserlerini meydana getirirken âdeta dili işlerler. Ayrıca günlük konuşmanın çok ötesinde sembollerle yüklü dilin kapılarını ardına kadar aralarlar. Popüler romanlarda ise; yazarlar, dile pek fazla önem vermezler. Elif Şafak, popüler yazarlar gibi eserinde içerik kaygısı taşıdığından dolayı üslubu geri planda bırakır. Sade, açık, anlaşılır bir dilin peşine düşen yazar, popüler

48 Şaban Sağlık, Popüler Roman Estetik Roman (Ankara: Akçă̆ Yayınları, 2010), 170. 
romanların izinde eserini oluşturur. Bunda Elif Şafak'ın Aşk'1yla her kesim okuyucuya hitap etme arzusu da etkilidir.

İngilizceden Türkçeye çevrilen eser, Türkçenin duygu dünyasını yansıtan kelimeleri okuyucuyla buluşturamaz. Eserde geçen; "Mamafih, 2008 yılı mayıs ayı"49, "Suratında da bir şişe sirke suyu içmek zorunda kalmış gibi ekşilik." 50 , "tüm gücünü emmiş"51, "midesinin ortasına koca bir taş gelip oturmuş gibi",52 "biteviye akıyordu zaman"53, "Kabil Habil'i öldürdükten kelli" ${ }^{54}$, her ikisini de tıka basa bezelyelerle, haşlanmış sebzelerle besledi" ${ }^{55}$ şeklindeki sözler; zaman zaman dilin zorlandığını, kelimelerin yanlış anlamda kullanıldığını, Türkçede var olmayan ifadelere yer verildiğini göstermektedir. Bütün bunlar romanı estetiklikten uzaklaştırır.

Aşk' ’n Türkçeye çevrilmesinde yazara K. Yiğit Us da katkı sağlar. Yazarın duygu ve düşünce dünyasını bir başkasının bilemeyeceği aşikârdır. Elif Şafak, nasıl oluyor da romanı dil ve üslubun zenginleştirebileceği kadar çoraklaştırabileceğini de görmezden gelerek eserini başkasıyla çevirebiliyor? Elbette bu soru, popülaritenin etkisine kapılmış bir yazarın pek kolay cevaplayabileceği türden değildir. Elif Şafak, Aşk’’ İngilizceden Türkçeye çevirirken K. Yiğit Us'un tasavvufi bilgisiyle çeviriye yardım ettiğini, eserinin de Türkçenin ritmine uygun olarak yeniden şekillendiğini söyler. ${ }^{56}$ Ritim; “Ahenk, uyum, ölçü, düzenlilik, itirâd. (...) Bir şiir veya düzyazıda tekrar edilen şeyin düzenliliğinden kaynaklanan; okuma veya dinleme esnasında hissedilen ahenktir. ${ }^{\circ 7}$ Yukarıda örnekleri verilen ifadelere bakıldığında eserde kullanılan dilin Türkçenin ritmine uygun olmadığı görülür. Elif Şafak, eserinin Türkçenin ritmine uygun şekilde çevrildiğini iddia etse de okuyucu bazı ifadelerin ne kadar kulak tırmaladığını fark eder. Görülüyor ki hem yazar hem de K. Yiğit Us, kendi ritimlerine göre eseri çevirirken bunun Türkçenin ritmi olduğuna inanmışlar.

\section{Sonuç}

Elif Şafak, Ella ve Zahara aşkını anlattığı kitabına Mevlana ve Şems hikâyesini de dâhil ederek piyasa romancılığına bir yenisini daha ekler. "Bu sufilik edebiyatı bir New Age modası! $\mathrm{Bu}$ aşk edebiyatı ise tam bir kitsch!" 58 Yazar, kitabının kapak rengiyle, satışıyla, anlatmak istediği şeyin ne olduğuyla ilgilendiğinden Mevlana ve Şems gibi değerli zatların popülerliğe kurban gittiğinin farkında bile değildir.

49 Şafak, $A s ̧ k, 17$.

50 Şafak, Aşk, 18.

51 Şafak, $A s ̧ k, 21$.

52 Şafak, $A s ̧ k, 23$.

53 Şafak, $A s ̧ k, 25$.

54 Şafak, $A s ̧ k, 39$.

55 Şafak, Aşk, 58.

56 Youtube. "Elif Şafak, CNN Türk Afiş Programı”, Erişim 02.03.2019. https://youtu.be/ RceXMG6WeTA

57 Turan Karataş, Ansiklopedik Edebiyat Terimleri Sözlüğü (İstanbul: İz Yayınc1lık, 2018), 277.

58 Yeni Şafak. “Aklın Kaleminden Kırk Kurallı Aşk.” Erişim 02.03.2019. https://www.yenisafak.com/yazarlar/ ducanecundioglu/aklin-kaleminden-kirk-kuralli-ak-18348 
Tasavvuf ya da kozmosu oluşturan beş ana element (toprak, su, rüzgâr, ateş ve boşluk) üzerine bir kitap kurgulamak eserleri estetik hâle getirmek için yeterli değildir. Aşk, gündemdeki olaylardan hareketle, yazar tarafından biçim ve içerik uyumu göz ardı edilerek sadece kişilerin duygularına hitap eden bir romandır. Elif Şafak; biraz estetik romanlardan biraz da popüler romanlardan beslenerek 2007 Unesco Mevlana Yılı'nın hemen ardından Aşk'ını kaleme alır. $A s ̧ k$, yazarın bahsedilen tutum/lar/ından dolayı melez bir hâldedir. Unutulmamalıdır ki yazarın popülerliği $A s ̧ k^{\prime}$ tan sonra tescillenir. Aşk'tan önce ve $A s ̧ k^{\prime}$ tan sonra Türkiye'de bambaşka bir Elif Şafak vardır. Tıpkı romandaki Ella gibi yazar da aşk sayesinde bambaşka bir hayatın içinde kendini bulur.

$A s ̧ k$, estetik kaygılardan uzak, popüler bir romandır. Eserde dil ve üslup yönünden kusurlar mevcut olduğu gibi, kurguda boşluk bırakılmadan her şey açık şekilde verilmiş, yoruma açık bir unsura yer verilmemiştir. Ayrıca, ilk baskıda pembe renkli olarak tasarlanan kitap kapağı erkek okuyucuların talebi üzerine gri renkli olarak da basılmış, yazar romanın tanıtımını yapmak için çeşitli programlara katılmıştır. Bunların yanında, yazar eserini kurgularken hiçbir zaman unutulmayacak tarihî kişileri romanın başkahramanı yaparak ortaya çıktığı hâlde $A s ̧ k^{\prime}$ ın belli bir süre adından bahsedildikten sonra unutulmuş olması romanın popüler olduğunun işaretlerinden bazılarıdır.

Elif Şafak, bu romanında "önemli kişilerin avcılığına soyunur." Onlardan hareketle romanlarına değer kazandırmak ister. Aşk ile başladığı bu serüvene Ustam ve Ben'le de devam eder. Yazarın içine düştüğü popüler olma sevdası ne yazık ki onu bir kısır döngüye çekmek üzeredir. Bir romanın değeri sadece bahsettiği konularla ölçülemez. Elif Şafak'ın $A s ̧ k^{\prime} 1$ popülerliğin gölgesindedir. Yazar, neyi anlattığı kadar nasıl anlattığının derdine düşmediği sürece eserleri bir yıldız gibi parladıktan sonra -tüm popüler romanlarda olduğu gibi- sönmeye mahkûm olacaktır.

Hakem Değerlendirmesi: Dış bağımsız.

Çıkar Çatışması: Yazarlar çıkar çatışması bildirmemiştir.

Finansal Destek: Yazarlar bu çalışma için finansal destek almadığını beyan etmiştir.

Peer-review: Externally peer-reviewed.

Conflict of Interest: The authors have no conflict of interest to declare.

Grant Support: The authors declared that this study has received no financial support.

\section{Kaynaklar/References}

And1, Fatih. Roman ve Hayat. İstanbul: Türk Edebiyatı Vakfı Yayınları, 2004.

Aytaç, Gürsel. Çağdaş Türk Romanları Üzerine İncelemeler. Ankara: Gündoğan Yayınları, 1990.

Baypınar, Yüksel, “Türk ve Alman Yı̆̆ın Edebiyatı -Edebiyat Tarihlerine Alınmayanlar-”, Ankara Üniversitesi DTCF Dergisi, 33/1-2, (1990): 42-63. 
Canbay, Belma. Türkiye’de Roman Yazarlarının Markalaşma Süreci: Elif Şafak Örneği. Yüksek Lisans Tezi, Ankara Üniversitesi, 2014.

Çakmakçı, Selami. Popüler Roman ve Muazzez Tahsin Berkand. Doktora Tezi, Fırat Üniversitesi 2012.

Eco, Umberto. Açık Yapıt. Çeviren Pınar Savaş. İstanbul: Can Yayınları, 2001.

Erdoğan, İrfan ve Korkmaz, Alemdar. Popüler Kültür ve İletişim. Ankara: Pozitif Matbaacılık, 2005.

Forster, E. M. “Düz ve Yuvarlak Karakterler”, Roman Teorisi. Hazırlayan Philip Stevick. Çeviren Sevim Kantarcıŏlu. Ankara: Akçağ Yayınları, 2017, 168-176.

İpşiroğlu, Zehra. Eleştirinin Eleştirisi. İstanbul: Cem Yayınevi, 1992.

Karataş, Turan. Ansiklopedik Edebiyat Terimleri Sözlüğü. İstanbul: İz Yayıncılık, 2018.

Moran, Berna. Edebiyat Kuramları ve Eleştiri. İstanbul: İletişim Yayınları, 2011.

Oktay, Ahmet. Türkiye'de Popüler Kültür. İstanbul: YKY, 1993.

Sağlık, Şaban. Popüler Roman Estetik Roman. Ankara: Akçağ Yayınları, 2010.

Şafak, Elif, Aşk. Çeviren K. Yiğit Us. İstanbul: Doğan Egmont Yayıncılık, 2009.

Tahir, Kemal. Notlar/Sanat-edebiyat. Hazırlayan Cengiz Yazoğlu. İstanbul: Bağlam Yayınc1lık, 1990.

Tekin, Mehmet. “Aşk Romanında Anlatıcının Halleri”, Yeni Türk Edebiyatı. 2, (2010): 103-116.

Tekin, Mehmet. “Tuhaf Bir Tezli Roman: Aşk”, Yeni Türk Edebiyatı Araştırmaları. 4, (Temmuz-Aralık 2010): $7-35$.

Tekin, Mehmet. Roman Sanatı Romanın Unsurları 1. İstanbul: Ötüken Neşriyat, 2010.

Tunalı, İsmail. Estetik. İstanbul: Remzi Kitabevi, 2013.

Turani, Adnan. Sanat Terimleri Sözlüğü. İstanbul: Remzi Kitabevi, 1993.

Turgut, İhsan. Sanat Felsefesi. İzmir: Bilgehan Matbaası, 1991.

Türkçe Sözlük, Ankara: Türk Dil Kurumu Yayınları, 2009.

Uğur, Veli. 1980 Sonrası Türkiye'de Popüler Roman. İstanbul: Koç Üniversitesi Yayınları, 2013.

Yıldız, Alpay Doğan. Popüler Türk Romanları Kerime Nadir, Esat Mahmut Karakurt, Muazzez Tahsin Berkant 1930-1950. İstanbul: Dergâh Yayınları, 2009.

\section{İnternet Kaynakları:}

CNN TÜRK. “Elif Şafak’ın Tasavvufa Olan İlgisi Nereden Geliyor?” Erişim 01.03.2019. https://www.cnnturk. com/video/2012/07/18/soru-cevap/biyografi/elif-safak-in-tasavvufa olan-ilgisi-nereden-geliyor/index.html

ElifŞafak.us. "Aşkı Bulmak İçin”, Erişim 02.03.2019. http://www.elifsafak.us/roportajlar.asp?islem= roportaj\&id $=290$

Kitapyurdu. “Aşkın Kırk Kuralı.” Erişim 02.03.2019. https://www.kitapyurdu.com/kitap/askin-kirk kurali/490917. html?gclid=EAIaIQobChMIxffSIN2b4QIVFobVCh1A1APREAYYAyABEgLVrPD_BE

Milliyet. "Maçolar için “AŞK”ın gri kapaklısı çıktı.” Erişim 02.03.2019. http://www.milliyet.com.tr/pembekapak-delikanliyi-bozdu---ask-grioldu/pazar/haberdetay/28.06.2009/1111421/default.htm

Sanatsal. "Pop Sanatı (Pop Art) Nedir, Ne Demektir?” Erişim 01.03.2019. http://www.sanatsal.gen.tr/popsanati-pop-art-nedir-ne-demektir/ 
Yeni Şafak. “Aklın Kaleminden Kırk Kurallı Aşk.” Erişim 02.03.2019. https://www.yenisafak.com/yazarlar/ ducanecundioglu/aklin-kaleminden-kirk-kuralli-ak-18348

Youtube. “Elif Şafak-Haber Türk Saba Tümer’le Bu Gece Programı”, Erişim 02.03.2019. https://www.youtube. $\mathrm{com} /$ watch? $\mathrm{v}=\mathrm{P}-\mathrm{OsUB} 4 \mathrm{UL} 6 \mathrm{~A}$

Youtube. "Elif Şafak-Samanyolu TV Kum Saati Programı", Erişim 02.03.2019. https://youtu.be/ChlTcmnTnhs

Youtube. “Elif Şafak, CNN Türk Afiş Programı”, Erişim 02.03.2019. https://youtu.be/RceXMG6WeTA 
